\title{
Loneliness among Elderly Population
}

\section{Kavita Verma ${ }^{1}$, Priyanka Setia ${ }^{2}$, Priyanka Bhardwaj ${ }^{3}$, Preeti Rawat ${ }^{4}$, Preeti Sharma $^{5}$}

\author{
${ }^{1}$ Lecturer, ${ }^{2}$ B. Sc. Nursing $4^{\text {th }}$ Year; \\ Akal College of Nursing, Eternal University, Baru Sahib, Distt Sirmour H.P. -173101
}

Corresponding Author: Kavita Verma

\begin{abstract}
Background: Old age or elderly is the final stage of the normal life span. The elderly population is facing many health problems such as physical, mental, psychological \& social etc. Factors like loneliness, low self-esteem, social isolation, quality of life and several others negatively affect elderly population and increase the risk of various health problems in elderly people.
\end{abstract}

Aim: This study aims to assess loneliness among elderly population and to examine possible correlations with associated demographic, social and health factors.

Methods: A cross sectional study was conducted, in which 200 elderly from Sirmour participated and the subjects were selected using total enumeration sampling technique. For the data collection the UCLA loneliness 20-item scale was used as well as a questionnaire with questions about demographic, social and health factors and the data was analyzed using descriptive and inferential statistics in SPSS.

Results: Present study results reveals $127(63.5 \%)$ of elderly has mild level of loneliness, $44(22.0 \%)$ of them has moderate level of loneliness whereas $29(14.5 \%)$ has severe level of loneliness and no significant association was found between the level of loneliness \& demographic variable.

Conclusion: Results show that no significant association is present between the loneliness with demographic variable.

Keywords: Loneliness, UCLA Scale.

\section{INTRODUCTION}

Old age or elderly or senescence, is the final stage of the normal life span. It is the stage of degeneration where atrophy of various body tissues, cells and muscles started due to various factors such as freeradicals formation, increase in cell rigidity, wear and tear of various body tissues and mutations of DNA under the influence of various harmful rays. (1) Help age India aim to serve elderly need in a holistic manner i.e. including all physical, mental, social, and spiritual aspect, enabling them to live their life with dignity and healthy. The Help age global network 2015 review reported that $12 \%$ of the global population $>60$ years of age and that by 2050 this $\%$ is estimated to rise to 324 million.

Help age India is a leading charity in India working with and for disadvantaged elderly for nearly 4 decades by providing them with pension, quality healthcare, action against elder abuse, cataract surgeries and also focusing on rehabilitation of elderly and making them self-reliant. (2) The rate of the elderly people in the world over 60 years between 2015 and 2050 will increase twice from $12 \%$ to $22 \%$. By 2050 , the world's people aged 60 years and above are predicted to be 2 billion, arise from 900 million in 2015. In 2018, 125 million people are aged 80 years or older. Up to $50 \%$ of those aged over 60 years are at risk of loneliness and about one third of old people will complain some degree of loneliness at old age $[3,4]$. 


\section{Significance of the study}

The Elderly population is facing many health problems such as physical, mental, psychological \& social etc. There are various studies conducted on the elderly population which suggests that the factors like loneliness, low self-esteem, social isolation, quality of life and several others which negatively affect elderly population. These factors increase the risk of various health problems in elderly people. This study focuses on loneliness among elderly age group and the impact of these factors on the health status of the elderly which directly helps in dealing with the problems faced by them in their day to day life to make it more meaningful \&worth full.

\section{Objectives of the study}

1. To assess the Loneliness among elderly residing in urban area of District Sirmour H.P).

2. To find association between Loneliness with selected Demographic variables.

\section{SUBJECTS AND METHODS}

Research Design: A cross-sectional analytical study

Study Setting: The research area for the research study is selected urban area of district Sirmour (HP).

Study Subjects: The sample of the study is elderly population of selected urban areas of district Sirmour (HP) and those time of data collection and who meets the inclusion criteria.

\section{Sample size}

$n=N Z 2 p(1-p) / d 2(N-1)+Z 2 p(1-p)$

$\mathrm{n}=$ Sample size

$\mathrm{N}=$ Total Population

$\mathrm{Z}=$ Standards normal variable with $95 \%$ confidence interval i.e. $1.96 \mathrm{~d}=$ (allowable error) $=5 \%=.05$

$\mathrm{p}=$ population proportion $=0.5$

The calculated sample size was 253 but due to scattered population of elderly people we took 200 as final study sample.
Sampling Technique: Total enumeration sampling technique is used.

\section{Inclusion criteria for quantitative} interview

1. Elderly who are willing to participate.

2. Elderly who are more cooperative and expressive.

3. Elderly present at the time of data collection.

\section{Exclusion criteria}

1. Elderly with deficits in higher mental functions (amnesia, aphasia).

2. Elderly with hearing and verbal impairments.

3. Elderly who are not cooperative and not willing to participate.

\section{Validity \& Reliability}

For the UCLA loneliness scale internal consistency (coefficient a ranging from .89 to .94 ) and test-retest reliability over a 1 -year period $(r=.73)$.

\section{Data collection instruments}

Tool 1: Semi structured interview schedule. Tool 2: UCLA loneliness Scale

\section{Tool 1: Semi structure interview schedule to ascertain the background information}

Part A of tool includes variables i.e. age, religion, total no. of family members, type of family, marital status, qualification, occupation, total monthly income of family, earning member of family.

\section{Tool 2: UCLA loneliness Scale}

UCLA Loneliness Scale was developed by psychologist Daniel Russell is a 20-item scale that assesses how often a person feels disconnected from others. Participants rate each item as either O ("I often feel this way"), S ("I sometimes feel this way"), $\mathrm{R}$ ("I rarely feel this way"), $\mathrm{N}$ ("I never feel this way")

\section{Scoring system}

Scoring: $0=4, S=3, R=2$, and $N=1$.

Total score range from low feeling of loneliness $=20<40$, mild feeling of 
loneliness $=40<60$, high feeling of loneliness $=60<$ _ 80 .

Higher score indicates greater degree of loneliness.

Method of data collection: The data was collected in the month of January 2020 by using following steps:

1. Participants were selected by using total enumeration sampling technique in the urban areas of district Sirmour.

2. Participants were informed about the aim and objectives of the study.

3. Written consent was obtained from each participant.

4. Full autonomy was given to the study participants to participate in research and withdraw at any time.

5. Data was collected regarding sociodemographic profile, clinical profile of the participants by using semi structured interview schedule and WHO quality of life scale, UCLA loneliness scale, Rosenberg self- esteem scale.

\section{Ethical Consideration}

1. Ethical approval for the study will be taken from the Ethical Committee of Eternal University.

2. The researcher has to explain the study to the participants and a written informed consent will be obtained from each subject.

3. Written permission for the data collection from Head of Municipal Corporation Rajgarh District Sirmour HP.

4. There will be no interference in the routine activities of sample while collecting data.

5. The anonymity and confidentiality of the participants in relation to findings will be protected while reporting the study.

6. Professional norms will be maintained.

\section{Statistical analysis}

After data were Collected, they were coded, and transferred into especially designed formats so as to be suitable for computer feeding following data entry checking and verification processes were carried out to avoid any errors during data entry process, frequency analysis, cross tabulation, and manual reversion were used to detect any errors.

The SPSS (statistical package of social sciences), version 23 was utilized for both data statistical analysis and presentati0n measures were used.

\section{RESULTS}

Table no.1: Depicts that $44(57.0 \%)$ of elderly belongs to the age group of 60-65 years, $47(23.5 \%)$ belongs to the age group of $65-70$ another $22(11.0 \%)$ belongs to the age group of 70-75 years and remaining $17(8.5 \%)$ belongs to the age group of 75 years and more. It was found out that $185(92.5 \%)$ of them belongs from Hindu religion and $6(3.0 \%)$ were from Muslim religion, 5(2.5\%) were from Christian, $4(2.0 \%)$ were from Sikhism. The $131(65.5 \%)$ has $5 \&$ more than 5 as total family members, $48(24.0 \%)$ of elderly has family members between 2-4 whereas $20(10.0 \%)$ of elderly has family members between 0-2. Majority of the elderly $136(68.0 \%)$ has joint families, $57(28.5 \%)$ of them belongs to the nuclear families whereas $7(3.5 \%)$ of elderly belongs to extended families. The 166(83.0\%) of elderly were married, 29(14.5\%) were widow and $5(2.5 \%)$ were divorced. The $71(35.5 \%)$ of the elderly has $4 \&$ more children, $68(34.0 \%)$ has 3 children, $40(20.0 \%)$ has 2 children and $21(10.5 \%)$ has 1 children. The $92(46.0 \%)$ of them were pre-literate, $55(27.5 \%)$ of has primary level of education, $45(22.5 \%)$ of them has secondary level of education whereas $8(4.0 \%)$ has metric level of education. Majority of $90(45.0 \%)$ were housewife, $67(33.5 \%)$ was working as labourer, $30(15.0 \%)$ was having private businesses and $13(6.5 \%)$ were government employees. The $144(72.0 \%)$ of elderly has family income less than $10,000,39(19.5 \%)$ of them has family income between Rs. 10,00020,000 , followed by $9(4.5 \%)$ of them has income between Rs. 20,000-30,000 and 
$8(4.0 \%)$ of them has family income more than 30,000 .

\begin{tabular}{|c|c|c|c|c|}
\hline Sr. No. & \multicolumn{2}{|c|}{ Variables } & f & $\%$ \\
\hline \multirow[t]{4}{*}{1.} & \multirow[t]{4}{*}{ Age (in years) } & $60-65$ & 114 & 57.0 \\
\hline & & $65-70$ & 47 & 23.5 \\
\hline & & $70-75$ & 22 & 11.0 \\
\hline & & $75 \&$ More & 17 & 8.5 \\
\hline \multirow[t]{4}{*}{2.} & \multirow[t]{4}{*}{ Religion } & Hindu & 185 & 92.5 \\
\hline & & Muslim & 6 & 3.0 \\
\hline & & Christian & 5 & 2.5 \\
\hline & & Sikhism & 4 & 2.0 \\
\hline \multirow[t]{3}{*}{3.} & \multirow{3}{*}{ Total family members } & $0-2$ & 20 & 10.0 \\
\hline & & $2-4$ & 48 & 24.0 \\
\hline & & $5 \&$ more than 5 & 132 & 66 \\
\hline \multirow[t]{3}{*}{4.} & \multirow[t]{3}{*}{ Type of family } & Nuclear & 57 & 28.5 \\
\hline & & Joint & 136 & 68.0 \\
\hline & & Extended & 7 & 3.5 \\
\hline \multirow[t]{3}{*}{5.} & \multirow[t]{3}{*}{ Type of marriage } & Married & 166 & 83.0 \\
\hline & & Divorced & 5 & 2.5 \\
\hline & & Widow & 29 & 14.5 \\
\hline \multirow[t]{4}{*}{6.} & \multirow[t]{4}{*}{ Total no of children } & 1 & 21 & 10.5 \\
\hline & & 2 & 40 & 20.0 \\
\hline & & 3 & 68 & 34.0 \\
\hline & & $4 \&$ more than 4 & 71 & 35.5 \\
\hline \multirow[t]{4}{*}{7.} & \multirow[t]{4}{*}{ Education status } & Pre-literate & 92 & 46.0 \\
\hline & & Primary education & 55 & 27.5 \\
\hline & & Secondary education & 45 & 22.5 \\
\hline & & Metric \& more & 8 & 4.0 \\
\hline \multirow[t]{4}{*}{8.} & \multirow[t]{4}{*}{ Occupation } & Government & 13 & 6.5 \\
\hline & & Private & 30 & 15.0 \\
\hline & & Labourer & 67 & 33.5 \\
\hline & & Housewife & 90 & 45.0 \\
\hline \multirow[t]{4}{*}{9.} & \multirow[t]{4}{*}{ Monthly income (in rupees) } & $<10,000$ & 144 & 72.0 \\
\hline & & $10000-20000$ & 39 & 19.5 \\
\hline & & $20000-30000$ & 9 & 4.5 \\
\hline & & $>30000$ & 8 & 4.0 \\
\hline
\end{tabular}

Table no.2: Frequency and percentage distribution of elderly based on UCLA scale.

\begin{tabular}{|c|c|c|}
\hline Assessing criteria & f & \% \\
\hline Mild loneliness & 127 & 63.5 \\
\hline Moderate loneliness & 44 & 22.0 \\
\hline Severe loneliness & 29 & 14.5 \\
\hline
\end{tabular}

Table no.2: This table depicts findings of UCLA scale in which $127(63.5 \%)$ of elderly has mild loneliness, 44(22.0\%) of them has moderate loneliness whereas $29(14.5 \%)$ has severe loneliness.

Table no. 3: Association of demographic variables with UCLA loneliness scale.

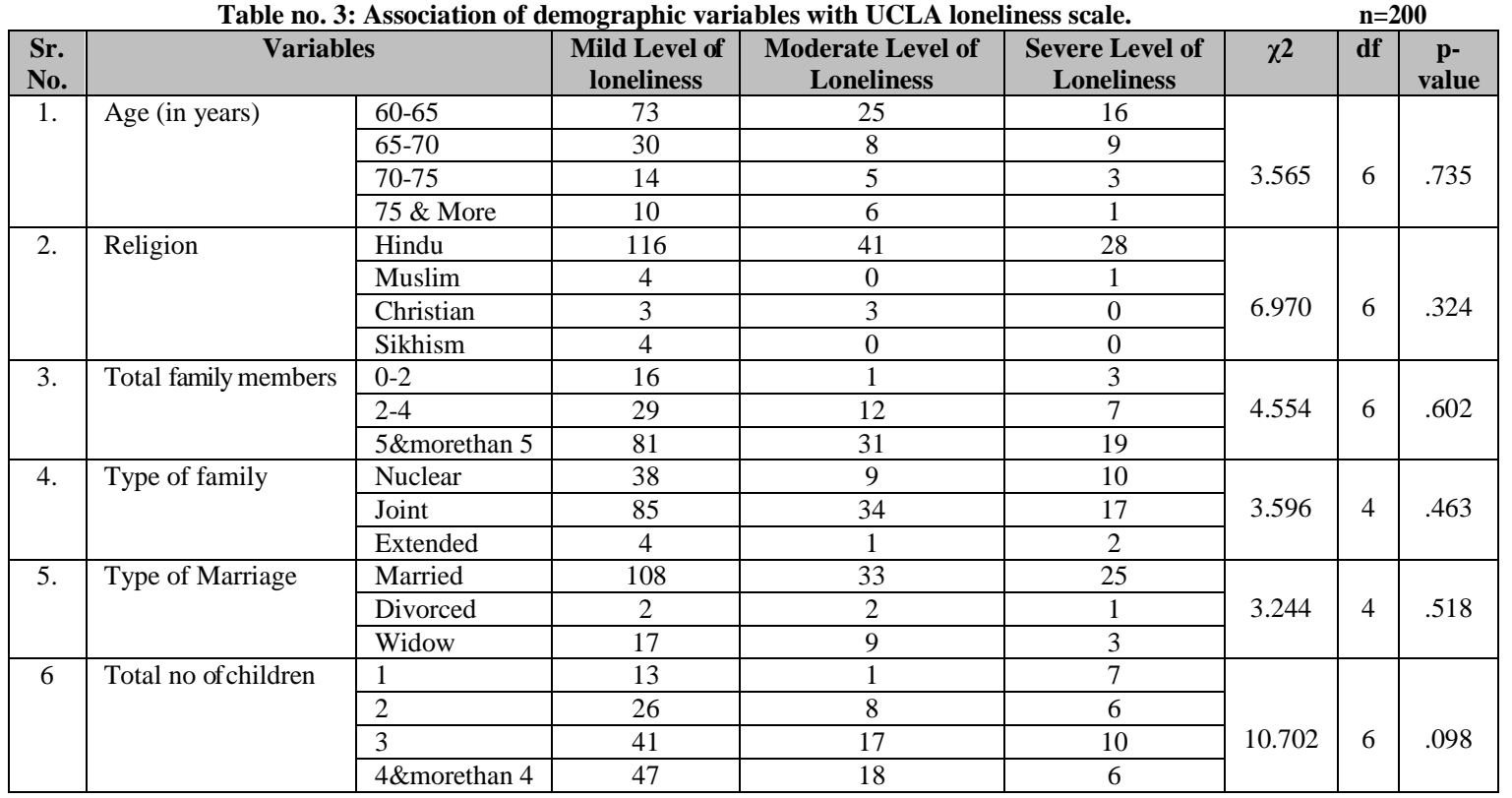




\begin{tabular}{|c|c|c|c|c|c|c|c|c|}
\hline \multicolumn{9}{|c|}{ Table no. 3 continued..... } \\
\hline \multirow[t]{4}{*}{7.} & \multirow[t]{4}{*}{ Education status } & Pre-literate & 63 & 18 & 11 & \multirow{4}{*}{5.156} & \multirow{4}{*}{6} & \multirow{4}{*}{524} \\
\hline & & Primary & 34 & 13 & 8 & & & \\
\hline & & Secondary & 27 & 11 & 7 & & & \\
\hline & & Metric\& more & 3 & 2 & 3 & & & \\
\hline \multirow[t]{4}{*}{8.} & \multirow[t]{4}{*}{ Occupation } & Government & 7 & 5 & 1 & \multirow{4}{*}{8.034} & \multirow{4}{*}{6} & \multirow{4}{*}{.236} \\
\hline & & Private & 15 & 8 & 7 & & & \\
\hline & & Labourer & 44 & 11 & 12 & & & \\
\hline & & Housewife & 61 & 20 & 9 & & & \\
\hline \multirow[t]{4}{*}{9.} & \multirow{4}{*}{$\begin{array}{l}\text { Monthly income } \\
\text { (in rupees) }\end{array}$} & $<10,000$ & 94 & 29 & 21 & \multirow{4}{*}{3.283} & \multirow{4}{*}{6} & \multirow{4}{*}{.773} \\
\hline & & $10000-20000$ & 22 & 10 & 7 & & & \\
\hline & & $20000-30000$ & 6 & 2 & 1 & & & \\
\hline & & $>30000$ & 5 & 3 & 0 & & & \\
\hline
\end{tabular}

\section{DISCUSSION}

Loneliness is upsetting feeling of social separation that occurs with the perception of inadequacy in the required figures or goodness of one's social connections. Loneliness is well reported as a prevailing problem among old people, because of life modifications and losses in aging [26,27] .

Present study results reveals $127(63.5 \%)$ of elderly has mild level of loneliness, $44(22.0 \%)$ of them has moderate level of loneliness whereas $29(14.5 \%)$ has severe level of loneliness. And no significant association was found between the level of loneliness \& demographic variable.

Similar results are shown in a crosssectional with objective to assess the loneliness and self-reported health among older persons in New Zealand. The purpose of the study was to identify the rate, degree and impact of loneliness in older people. The sample size was 332 older 45 people and tool used was questionnaire. The findings revealed $8 \%$ of were severely lonely, 44\% were moderately lonely and $48 \%$ were not lonely. It was concluded that the difference was found in the physical and mental status of the older people due to loneliness. $^{(7)}$

No significant association was found between the loneliness with demographic variable. Research work indicates that Breath-walk is helpful in managing common forms of anxiety and moderate depression with a focus on breaths of the clients. It changes our negative mood into positive and gives a sense of fulfillment, accomplishment \& fulfillment for elderly. (8)

\section{RECOMMENDATION}

1. Similar studies can be conducted on the self-esteem.

2. The study can be replicated on large samples.

3. The findings could be used to inform the development of various new researches on the geriatric population.

4. The same study can be done using various other research methodology and research designs like meta-analysis, longitudinal, cross-sectional, prospective, observational and surveybased study.

\section{Acknowledgement: None}

\section{Conflict of Interest: None}

\section{Source of Funding: None}

\section{Ethical Approval: Approved}

\section{REFERENCES}

1. Ansari J. textbook of medical surgical nursing-2 Jalandhar: S.Vikas and company (medical publishers) India 2017

2. Madan Mohan Sabharwal on Bloomberg. Bloomberg.2016. retrived 29 January 2016. (Accessed on https:// en.m. Wikipedia. Org/ wiki/ Helpage- India on dated 17 January 2020.

3. LANDEIRO F., BARROWS P., MUSSON E.N., GRAY A.M. and LEAL J.: Reducing social isolation and loneliness in older people: A systematic review protocol. BMJ Open. 2017 May 17;7(5):e013778. doi: 10.1136/bmjopen-2016-013778. 
4. World Health Organization: Ageing and health, retrieved from https://www.who.int/news-room/factsheets/detail /ageing-and-health, 2018.

5. COYLE C.E. and DUGAN E.: Social isolation, loneliness and health among older adults. Journal of Aging and Health, 24 (8): 1346-1363, 2012.

6. MATLABI H., HAMEDI BEHTASH H. and SHAFIEI M.: Admission to a nursing home: Viewpoints of institutionalized older people about replacement. Elderly Health Journal, 2 (1): 1-5, 2016.

7. Laiteerapong N, Karter AJ, Liu JY, Moffet $\mathrm{HH}$, Sudore R, Schillinger D, John PM, Huang ES. Correlates of quality of life in older adults with diabetes: the diabetes \& aging study. Diabetes care. 2011 Aug 1;34(8):1749-53.

8. Khalsa MK, Verma $K$, Sharma $A$. Meditation and motion: A Need of the hour. Available from: https://www.researchgate.net/publication/34 2095445_Meditation_and_motion_A_Need _of_the_hour [accessed May 29 2021].

How to cite this article: Verma K, Setia $\mathrm{P}$, Bhardwaj $\mathrm{P}$ et.al. Loneliness among elderly population. International Journal of Science \& Healthcare Research. 2021; 6(2): 235-240. DOI: https://doi.org/10.52403/ijshr.20210442 